\title{
ТАКТИЧНІ ОСОБЛИВОСТІ ДОПИТУ ПІДОЗРЮВАНИХ У СТВОРЕННІ ТЕРОРИСТИЧНОӦ ГРУПИ ЧИ ТЕРОРИСТИЧНОЇ ОРГАНІЗАЦІЇ
}

Мальгіна А. С., Горбаньов І. М.

Статтю присвячено висвітленню основних тактичних особливостей допиту підозрюваного у вчиненні злочину, передбаченого статтею 258-3 Кримінального кодексу України «Створення терористичної групи чи терористичної організації». Зокрема, проведено аналіз останніх досліджень та публікацій, що стосуються цього питання. Наведено статистичні дані, що вказують на актуальність такої теми для правоохоронних органів країни. Викладено основні вимоги до проведення зазначеної слідчої (розшукової) дії, що передбачені кримінально-процесуальним національним законодавством. Звертається увага на те, що ця слідча (розшукова) дія вимагає ретельної підготовки слідчого, оскільки терористичні угруповання є специфічним видом організованих злочинних угруповань, в основі яких лежать політичні, ідеологічні, соціальні та економічні мотиви. Зазначається, що для досягнення ефективного результату складається письмовий план допиту. Предметом допиту підозрюваного у створенні терористичної групи чи терористичної організації $\epsilon$ : інформація про появу злочинного плану створення, участі в терористичній організації; способи підготовки та вчинення злочинів, послідовність злочинних дій, а також особливості приховування терористичної діяльності; час, місце, обставини та механізм учинення злочинів; інформація про особу керівника або організатора терористичної організації та ії учасників; структуру терористичної групи (кількісний та якісний склад, рівень організаціі) та розподіл функціональних обов'язків тощо. У статmі проаналізовано основні тактичні прийоми, що використовуються слідчими для отримання показань від підозрюваного - члена терористичної групи чи організації. Також визначено найбільш сприятливий час для проведення вказаної слідчої (розшукової) дії. Робиться висновок, що показання учасника терористичного угруповання необхідно оцінювати лише в сукупності з іншими, вже перевіреними доказами.

Ключові слова: терористична група, терористична організація, тактика, допит, тактичні прийоми, підозрюваний, слідча (розшукова) дія.

(c) Мальгіна А. С., Горбаньов І. М., 2020
Malhina A. S., Gorbanov I. N. Tactical features of interrogation of suspects in the formation of a terrorist group or terrorist organization

The article is devoted to the coverage of the main tactical features of the interrogation of a suspect in the commission of a crime under Article 258-3 of the Criminal Code of Ukraine "Creation of a terrorist group or terrorist organization". In particular, an analysis of recent research and publications that address this issue. The statistical data indicating urgency of such subject for law enforcement agencies of the country are resulted. The basic requirements for carrying out the specified investigative (search) action provided by the criminal procedural national legislation are stated. Attention is drawn to the fact that this investigative (investigative) action requires careful preparation by the investigator, as terrorist groups are a specific type of organized criminal groups, the basis of which is based on political, ideological, social and economic motives. It is noted that a written plan of interrogation is drawn up to achieve an effective result. The subject of interrogation of a suspect in the creation of a terrorist group or terrorist organization is: information about the emergence of a criminal plan to create, participate in a terrorist association; ways of preparation and commission of crimes, sequence of criminal actions, and also features of concealment of terrorist activity; time, place, situation and mechanism of committing crimes; information about the identity of the leader or organizer of the terrorist association and its members; identification of the structure of a terrorist group (quantitative and qualitative composition, level of organization) and distribution of functional responsibilities; etc. The article analyzes the main tactics used by investigators to obtain testimony from a suspect a member of a terrorist group or organization. The most favorable time for carrying out the specified investigative (search) action is also defined.

Key words: terrorist group, terrorist organization, tactics, interrogation, tactics, suspect, investigative (search) action.

Постановка проблеми та іï актуальність. Тероризм $\epsilon$ визначальною темою сучасної епохи. Хоча витоки цього феномену йдуть приблизно на два тисячоліття назад, він настільки 
актуальний, що теракти і спроби держав протистояти йому практично не залишають стрічок новин ось уже два десятиліття. Тероризм не тільки тягне за собою насильство, а й $є$ актом ідеологічної комунікації, а також психологічної війни проти суспільної моралі й державного апарату [5, с. 5].

Зусилля всіх держав та міжнародних організацій направлені на протидію цьому соціально-небезпечному явищу, що виражається в прийнятті численних міжнародних нормативно-правових актів та їх імплементації в національні законодавства, які встановлюють жорстку кримінальну відповідальність за тероризм та передбачають заснування відповідних національних силових відомств.

За останні сім років питання боротьби з терористичними проявами як ніколи гостро постало і для України. На сучасному етапі правоохоронним органам України доводиться боротися з терористичною діяльністю учасників незаконних збройних формувань так званих «Донецької Народної Республіки» та «Луганської Народної Республіки» за допомогою проведення оперативно-розшукових заходів та слідчих (розшукових) дій у рамках кримінальних проваджень, з метою притягнення вказаних осіб до відповідальності, передбаченої законодавством, i відновлення територіальної цілісності нашої держави.

Натепер статтею 258-3 Кримінального кодексу України передбачено відповідальність за створення, керівництво, участь у терористичній групі чи терористичній організації або інше сприяння створенню таких угруповань [3]. 3 огляду на соціальні, політичні та психологічні аспекти, що зумовлюють створення терористичних угруповань, надзвичайно актуальним $€$ дослідження тактичних особливостей допиту підозрюваних у вчиненні кримінального правопорушення, передбаченого наведеною статтею.

Аналіз останніх досліджень і публікацій. У криміналістичній літературі досить повно описано основні прийоми та методи тактики проведення допиту, зокрема в наукових працях таких учених, як В.П. Бахін, Р.С. Бєлкін, П.Д. Біленчук, В.К. Весельський, В.О. Коновалова, Є.М. Ліфшиц, Т.С. Маліков, В.Ю. Шепітько, М.Є. Шумило та ін.

Крім того, питання тактики допиту учасників злочинних угруповань вивчали у своїх працях К.О. Чаплинський «Організація і тактика слідчих дій при розслідуванні злочинів, вчинених організованими злочинними угрупованнями», Л.В. Дергач «Особливості проведення допиту підозрюваних у справах про вимагання, вчинені організованими злочинними групами», О.І. Романов «Первоначальный этап расследования уголовных дел об организации преступного сообщества (преступной организации)» та інші.

У свою чергу дослідженню питання тактики проведення допитів під час розслідування злочинів терористичної спрямованості приділяли увагу у своїх роботах Я.С. Вєлічкін та І.С. Фомін «Некоторые методические и тактические особенности расследования уголовных дел о преступлениях террористической направленности", І.П. Кравець «Тактические приемы, применяемые при допросе в процессе расследования преступлений, связанных с террористическими актами», П.Д. Біленчук, А.П. Гель, Г.С. Семаков «Криміналістична тактика і методика розслідування окремих видів злочинів», О.П. Мілевський «Розслідування терористичних проявів (тактичні прийоми проведення окремих слідчих дій)» та інші.

Однак, на нашу думку, існуючі наукові праці фрагментарно висвітлюють тактичні особливості допиту осіб, підозрюваних у створенні терористичної групи чи терористичної організації. Починаючи з 2014 року, у зв'язку з діяльністю незаконних збройних формувань так званих «ДНР» та ЛНР» на Сході України слідчими органів безпеки напрацьовано певний досвід у проведенні допитів осіб під час розслідування злочинів терористичної спрямованості, спираючись на який, можна дослідити та узагальнити це питання.

Метою статті $\epsilon$ визначення основних тактичних особливостей допиту підозрюваного у створенні терористичної групи чи терористичної організації.

Виклад основного матеріалу. Допит $\epsilon$ найбільш поширеною слідчою (розшуковою) дією, без проведення якої не обійдеться жодне кримінальне провадження.

3 кримінально-процесуальної точки зору допит - це передбачена кримінальним процесуальним законом слідча (розшукова) дія, яка полягає в одержанні суб'єктом розслідування від свідка, потерпілого, підозрюваного, обвинуваченого, експерта показань про обставини, що мають значення для кримінального провадження [6, с. 373]. Однак таке визначення $\epsilon$ досить формалізованим та не розкриває самої сутності поняття допиту. Р.С. Бєлкін визначає допит як процес отримання показань від особи, яка володіє відомостями, що мають значення для розслідуваної справи [7, c. 599].

Найбільш детальне та влучне визначення поняттю «допит», на нашу думку, надав В.Ю. Шепітько, згідно з яким допит - це процесуальна дія, яка являє 
собою регламентований кримінально-процесуальними нормами інформаційно-психологічний процес спілкування осіб, котрі беруть у ньому участь, та спрямований на отримання інформації про відомі допитуваному факти, що мають значення для встановлення істини [8, с. 252].

Як зазначають дослідники, допит $\epsilon$ однією 3 найскладніших слідчих (розшукових) дій [7, с. 599; 8, с. 252; 9, с. 357; 10, с. 97], оскільки слідчому досить часто протистоїть особа, яка не бажає давати показання або, навпаки, особа надає занадто великий обсяг інформації, серед якого необхідно виокремити лише ту, яка має значення для кримінального провадження.

У психологічному та емоційному аспекті найскладнішим видом цієї слідчої (розшукової) дії $\epsilon$ допит саме підозрюваного, оскільки встановлення психологічного контакту слідчого з особою, підозрюваною у вчиненні того чи іншого кримінального правопорушення, потребує додаткових зусиль, надзвичайної професійної майстерності та досвіду.

3 метою повної та всебічної характеристики тактичних прийомів допиту підозрюваних у створенні терористичних груп чи терористичних організацій необхідно для початку описати основні вимоги до проведення вказаної слідчої (розшукової) дії, що передбачені кПК України.

Відповідно до статті 224 КПК України перед проведенням допиту встановлюється особа, роз'яснюються іï права, а також порядок проведення допиту. Сам допит не може продовжуватися без перерви понад дві години, а в цілому - понад вісім годин на день. Крім того, під час допиту може застосовуватися фотозйомка, аудіо- та/або відеозапис. Важливим положенням $є$ те, що в разі відмови підозрюваного відповідати на запитання, давати показання особа, яка проводить допит, зобов' язана його зупинити одразу після отримання такої заяви [2]. Така норма обумовлена положенням, передбаченим статтею 63 Конституції України, відповідно до якої особа не несе відповідальність за відмову давати показання або пояснення щодо себе, членів сім'ї чи близьких родичів, коло яких визначається законом [1]. За бажанням допитуваної особи вона має право викласти свої показання власноручно. За письмовими показаннями особи їй можуть бути поставлені додаткові запитання [2].

Для нашого дослідження важливим $€$ окреслити статус підозрюваного. Так, згідно зі статтею 42 КПК України, підозрюваною $є$ особа, якій у порядку, передбаченому статтями 276-279 КПК
України, повідомлено про підозру, особа, яка затримана за підозрою у вчиненні кримінального правопорушення, або особа, щодо якої складено повідомлення про підозру, однак його не вручено їй внаслідок не встановлення місцезнаходження особи, проте вжито заходів для вручення у спосіб, передбачений КПК України для вручення повідомлень [2]. Санкцією статті 258-3 КК України передбачено покарання у вигляді позбавлення волі на строк від восьми до п'ятнадцяти років з конфіскацією майна або без такої, тому відповідно до статті 12 КК України вказаний злочин $є$ особливо тяжким [3]. У такому випадку, відповідно до вимог статті 52 КПК України, участь захисника $є$ обов'язковою у кримінальному провадженні щодо особливо тяжких злочинів та забезпечується з моменту набуття особою статусу підозрюваного [2].

Таким чином, слідчому необхідно врахувати, що під час проведення допиту підозрюваного у вчиненні створення терористичної групи чи терористичної організації буде присутній захисник, що впливає на тактику проведення такої слідчої (розшукової) дії.

Оскільки терористична група чи організація $\epsilon$ одним із різновидів злочинного угруповання, тому під час допиту підозрюваного у вчиненні злочину, передбаченого 258-3 КК України, використовуються тактичні прийоми для допиту учасників таких угруповань з урахуванням специфіки терористичних об'єднань, в основі створення яких лежать певні політичні, економічні, соціальні та ідеологічні мотиви.

Звертаючись до національного антитерористичного законодавства, слід відзначити, що в статті 1 Закону України «Про боротьбу з тероризмом» тероризм визначено як суспільно небезпечну діяльність, яка полягає у свідомому, цілеспрямованому застосуванні насильства шляхом захоплення заручників, підпалів, убивств, тортур, залякування населення та органів влади або вчинення інших посягань на життя чи здоров'я ні в чому не винних людей або погрози вчинення злочинних дій $з$ метою досягнення злочинних цілей. Відповідно до вказаного Закону терористична діяльність - це діяльність, яка охоплює: планування, організацію, підготовку та реалізацію терористичних актів; підбурювання до вчинення терористичних актів, насильства над фізичними особами або організаціями, знищення матеріальних об'єктів у терористичних цілях; організацію незаконних збройних формувань, злочинних угруповань (злочинних організацій), організованих злочинних груп для вчинення терористичних 
актів, так само як і участь у таких актах; вербування, озброєння, підготовку та використання терористів; пропаганду і поширення ідеології тероризму; проходження навчання тероризму; виїзд з України та в'їзд в Україну з терористичною метою; фінансування та інше сприяння тероризму [4].

П.Д. Біленчук відзначив, що терористична група - це підрозділ терористичної організації, який характеризується тісною взаємодією їі членів, об'єднаних конкретними цілями, і складається з терористів, що беруть безпосередню участь у терористичній діяльності. Терористична діяльність характеризується численністю рядів, порівняно тривалим часом існування, наявністю керівної ієрархї, поділом функцій керування і здійснення терористичних акцій, розвідки, пропаганди і фінансування [11, с. 363-364].

Із проаналізованих матеріалів кримінальних проваджень установлено, що так звані «ДНР» та «ЛНР» визначаються як стійкі ієрархічні об'єднання - терористичні організації, учасники якої в Україні займаються вчиненням терористичних актів, залякуванням населення, вбивством людей, захопленням адміністративних будівель органів державної влади і місцевого самоврядування та інших тяжких і особливо тяжких злочинів, що призводить до дестабілізації суспільнополітичної ситуації в державі. Основною метою діяльності вказаних терористичних організацій $\epsilon$ насильницька зміна та повалення конституційного ладу, захоплення державної влади в Україні, а також зміна меж території і державного кордону України у спосіб, що суперечить порядку, встановленому Конституцією України [15].

Хоча кримінальне правопорушення, передбачене статтею 258-3 КК України, віднесено до категорії злочинів проти громадської безпеки, однак на прикладі незаконної терористичної діяльності учасників так званих «ДНР» та «ЛНР» можна зробити висновок, що такі дії несуть насамперед загрозу основам національної безпеки.

Зокрема, статтею 258-3 КК України визначено відповідальність за такі форми здійснення терористичної діяльності: 1) створення терористичної групи чи терористичної організації; 2) керівництво такою групою чи організацією; 3) участь у такій групі чи організації; 4) організаційне чи інше сприяння створенню або діяльності терористичної групи чи терористичної організації [3].

3 урахуванням усіх вищезазначених дефініцій слідчому необхідно досить ретельно підготуватися до проведення допиту підозрюваного у вчи- ненні кримінального правопорушення, передбаченого статтею 258-3 КК України.

Як зазначає К.О. Чаплинський, допит членів організованих злочинних угруповань, у нашому випадку - терористичних об'єднань, та їхніх лідерів складається з трьох етапів: 1) підготовка до проведення допиту (підготовчий етап); 2) безпосередній допит (робочий етап); 3) фіксація ходу та результатів допиту (заключний етап) [12, с. 187].

Перед початком проведення допиту підозрюваного слідчий детально вивчає матеріали кримінального провадження: дані про особу підозрюваного (вік, стать, рівень освіти, рід занять, наявність або відсутність судимостей, характеристики за останнім відомим місцем проживання чи місцем роботи, сімейні відносини, соціальний статус, умови проживання, спосіб життя, політичні, ідеологічні переконання тощо); протоколи допиту свідків, протоколи огляду інформації, яка міститься на соціальних сторінках підозрюваних у мережі Інтернет; протоколи обшуків чи оглядів, матеріали за результатами проведення негласних (слідчих) розшукових дій; наявні речові докази тощо. Для досягнення ефективного результату перед початком допиту слідчому необхідно скласти письмовий план його проведення з чітким переліком питань, які стосуються обставин учинення кримінального правопорушення.

На основі рекомендацій, розроблених К.О. Чаплинським для допиту членів організованих злочинних угруповань [12, с. 189-190], до предмету допиту підозрюваного у створенні терористичної групи чи терористичної організації можна віднести з'ясування таких обставин: відомості про виникнення злочинного задуму на створення, участь у терористичному об'єднанні чи інше сприяння діяльності таких об'єднань; відомості щодо мотиву злочину та відношення підозрюваної особи до злочинних наслідків; способи підготовки та вчинення злочинів, послідовність злочинних дій, а також особливості приховування терористичної діяльності (їі характер); час, місце, обстановка та механізм учинення злочинів; відомості про особу злочинця (керівника або організатора терористичного об'єднання та його членів); умови, за яких допитуваний спостерігав будь-які предмети або явища; психологічний та фізичний стан особи в момент сприйняття чи після нього; загальна здібність допитуваного до певного сприйняття, запам'ятовування та відтворення; обставини, що сприяли або перешкоджали 
вчиненню злочинів; способи, мотиви формування терористичного угруповання (залучення до складу угруповання) та характер терористичної діяльності; виявлення психологічної та функціональної структури терористичного угруповання (кількісний та якісний склад, рівень організованості) і розподілу функціональних обов'язків; кількісний склад угруповання під час вчинення кожного епізоду терористичної діяльності, конкретної дії кожного, в тому числі навички володіння зброєю та прийомами боротьби; характер міжособистісних відносин усередині угруповання, а також вивчення психологічних та особистісних якостей членів терористичного угруповання; виявлення осіб, які не брали безпосередньої участі в скоєних злочинах, але обізнаних про їх підготовку, вчинення або приховання; наявність корумпованих зв'язків та зв'язків з іншими злочинними, терористичними групами; способи протидії досудовому розслідуванню та впливу на потерпілих, свідків і членів групи, які дають правдиві показання; відомості про озброєність, засоби зв'язку та технічну оснащеність злочинців; наявність у терористичній групі конфліктів, протиріч та розбіжностей; встановлення осіб, які залишилися на волі і продовжують терористичну діяльність або налагоджують зв'язки між членами угруповання та намагаються створити єдину, вигідну для всіх лінію поведінки тощо.

Як правило, з тактичної точки зору допит підозрюваного у створенні терористичної групи чи організації найкраще проводити одразу після затримання або вручення письмового повідомлення про підозру, тобто в той час, коли особа перебуває у збудженому емоційному стані, нервує та може розгубитися. У цей момент підозрювані надають найбільш правдиві та повні відомості, оскільки не досить добре керують своїми емоціями, не встигають повністю проаналізувати та обдумати свою позицію. Однак, як нами вже було зазначено, участь захисника у вказаній категорії кримінальних проваджень $€$ обов'язковою, що може ускладнити слідчому отримання від підозрюваного повних та достовірних показань.

Тому важливо звернути увагу на те, що тактика допиту залежить від того, $є$ він безконфліктним чи конфліктним. Безконфліктна ситуація характеризується повним або частковим збігом інтересів учасників взаємодії, відсутністю суперечностей у цілях, для досягнення яких спрямовані їхні зусилля на цьому етапі розслідування. За безконфліктної ситуації основне тактичне завдання слідчого полягає в детальному й вичерпному 3'ясуванні та фіксації в протоколі показань допитуваного. Для конфлікту типовою $є$ така ситуація, коли сторони прагнуть до протилежних цілей і під час планування своїх дій ураховують можливі дії протилежної сторони, взаємно створюють труднощі, щоб забезпечити необхідний для них результат [13, с. 175].

Під час допиту організаторів та членів терористичних угрупувань дуже часто виникають такі ситуації: 1) відмова від дачі показань на підставі статті 63 Конституції України; 2) повідомлення завідомо неправдивих відомостей. При цьому важливо пам'ятати, що підозрюваний, на відміну від свідка чи потерпілого, не несе відповідальності за дачу завідомо неправдивих показань. Для попередження й усунення таких конфліктних ситуацій слідчому необхідно встановити психологічний контакт із підозрюваним, установити мотиви небажання надання ним відомостей та переконати його в необхідності співпраці зі слідчим, оскільки активне сприяння розкриттю кримінального правопорушення відноситься до однієї з пом'якшуючих обставин (ст. 66 КК України) [3].

Якщо ж слідчому вдалося встановити психологічний контакт з підозрюваним, то в такому разі необхідно домогтися від останнього максимально повних та детальних показань. Із цією метою слідчі використовують різноманітні тактичні прийоми, які у криміналістичній літературі визначаються як найбільш раціональні способи або найбільш доцільна лінія поведінки слідчого в процесі збирання, дослідження та використання доказів [14, с. 179].

Опитування 187-ми співробітників СБУ показало, що до найбільш ефективних тактичних прийомів, що застосовуються слідчими під час допиту підозрюваних у створенні терористичної групи чи терористичної організації, відносяться: встановлення психологічного контакту, виклад показань підозрюваним у формі вільної розповіді, постановка запитань, пред'явлення доказів, використання технічних засобів фіксації, актуалізація забутого в пам'яті допитуваного, створення напруги, використання конфліктів усередині терористичних угруповань. Детально зупинимось на деяких із них.

Так, під час викладу підозрюваним своїх показань у формі вільної розповіді він може повідомити: важливі деталі про осіб, які разом із ним брали участь у терористичній діяльності; передумови та мотиви, які вплинули на його рішення щодо участі у терористичному угрупованні; 
керівників та організаторів терористичних угруповань; місця дислокації, населені пункти, де проводилась терористична діяльність підозрюваним, та інші відомості, які мають значення для кримінального провадження. За такими показаннями слідчий, як правило, задає уточнюючі та деталізуючі питання, за допомогою яких можливо виявити неправдиві відомості або, навпаки, підтвердити факти, встановлені під час досудового розслідування.

Також під час допитів членів терористичних угруповань доцільним є застосування аудіо/відеозапису, оскільки досить часто виникає ситуація, коли підозрюваний відмовляється від своїх показань із посиланням на те, що він давав такі свідчення під дією фізичного або психічного тиску з боку слідчого. Крім того, такий прийом надає можливість проаналізувати реакцію підозрюваного на ті чи інші питання слідчого, виявити неправдиві показання за мімікою, жестикуляцією, емоційним станом допитуваного.

Надзвичайно важливим тактичним прийомом $\epsilon$ використання конфлікту всередині терористичного угруповання. 3 огляду на складну організаційну та ієрархічну структуру так званих «ДНР» та «ЛНР», які вважають себе саме «республіками», тобто певними квазідержавними утвореннями, наявність такого конфлікту не викликає сумніву. Це може виражатись у невдоволенні політикою, яку здійснюють органи влади так званих «ДНР» та «ЛНР», вказівками та наказами окремих керівників терористичного угруповання, неотримання обіцяної матеріальної винагороди за участь у незаконній діяльності так званих «ДНР» та «ЛНР» тощо.

Тактичні прийоми можуть бути використані лише в сукупності, в поєднанні різних прийомів залежно від ситуації та особи підозрюваного. Правильно визначена послідовність використання тактичних прийомів надає можливість отримати бажані показання від підозрюваного, від яких може залежати увесь подальший хід досудового розслідування.

Висновки. Таким чином, тактичні особливості допиту осіб, підозрюваних у вчиненні злочину, передбаченого статтею 258-3 КК України, зумовлюються специфічною організаційною структурою терористичних об'єднань, мотивами їх створення, метою злочинної діяльності та безпосередньо місцем учасника в ієрархічній структурі такого об'єднання. Ефективність допиту підозрюваного у створенні терористичної групи чи терористичної організації напряму залежить від підготовки слідчого до проведення вказаної слідчої (розшукової) дії, його професійності, досвіду та критичного аналізу отриманої інформації, дотримання загальних криміналістичних рекомендацій та вимог процесуального законодавства для проведення допиту. Показання учасника терористичного угруповання необхідно оцінювати лише в сукупності з іншими доказами, отриманими в ході здійснення досудового розслідування.

\section{Література}

1. Конституція України: прийнята на п'ятій сесії Верховної Ради України 28 червня 1996 року. Відомості Верховної Ради України. 1996. № 30. Ст. 141. URL: https://zakon.rada.gov.ua/laws/show/638-15 (дата звернення: 03.12.2020).

2. Кримінальний процесуальний кодекс України : Закон України від 13.04.2012 р. № 4651-VI. Відомості Верховної Ради України. 2013. № 9-10, № 11-12, № 13. Ст. 88. URL: https://zakon.rada.gov.ua/ laws/show/638-15 (дата звернення: 03.12.2020).

3. Кримінальний кодекс України : Закон України від 05.04.2001 р. № 2341-ІІІ. Відомості Верховної Ради України. 2001. № 25-26. Ст. 131. URL: https://zakon.rada.gov.ua/laws/show/638-15 (дата звернення: 03.12.2020).

4. Про боротьбу з тероризмом : Закон України від 20.03.2003 p. № 638-IV. URL: https://zakon.rada.gov.ua/ laws/show/638-15 (дата звернення: 03.12.2020).

5. Типовой учебный план по борьбе с тероризмом (Counter-Terrorism Reference Curriculum, СTRC) NATO. URL: https://www.nato.int/nato_static_fl2014/ assets/pdf /2020/9/pdf/200612-DEEP-CTRC-rus.pdf (дата звернення: 03.12.2020).

6. Кримінальний процес : підручник / Ю.М. Грошевий та ін. Харків : «Право», 2013. 824 с.

7. Криминалистика : учебник для вузов / Т.В. Аверьянова и др. Москва : НОРМА (НОРМА-ИНФPA M), 2001. 990 с.

8. Криміналістика : підручник / В.М. Глібко та ін. ; за ред. В.Ю. Шепітька. Київ : «Видавничий Дім «اн Юре», 2001. 684 с.

9. Маркусь В.О. Криміналістика : навчальний посібник. Київ : Кондор, 2007. 558 с.

10. Белкин Р.С., Лифшиц Е.М. Тактика следственных действий. Москва, 1997. 176 с.

11. Біленчук П.Д., Гель А.П., Семаков Г.С. Криміналістична тактика і методика розслідування окремих видів злочинів : навч. посіб. Київ : МАУП, 2007. 512 c.

12. Чаплинський К.О. Тактичне забезпечення розслідування злочинів, вчинених злочинними угрупованнями : монографія. Дніпропетровськ : ДДУВС, 2009. 401 c. 
13. Климчук М.П., Фурман Я.В. Тактичні особливості допиту підозрюваних - членів організованих злочинних угруповань. Юридичний науковий електронний журнал. 2017. № 1. С. 174-177. URL: http://www.lsej.org.ua/1_2017/45.pdf (дата звернення: 03.12.2020).

14. Бахін В.П., Гора І.В., Цимбал П.В. Криміналістика: Курс лекцій. Ірпінь : Академія ДПС України, 2002. Ч. 1. 15. Ухвала слідчого судді Приморського районного суду міста Одеси від 17.05.2018 р. у справі № 522/7197/18, провадження № 1-кс/522/8996/18. URL: https://reyestr.court.gov.ua/Review/74089043 (дата звернення: 03.12.2020).
Мальгіна А. С., аспірант кафедри криміналістики та психології Одеського державного університету внутрішніх справ Горбаньов І. М., кандидат юридичних наук, дочент, професор кафедри криміналістики та психології одеського державного університету внутрішніх справ 